\title{
Eating Difficulties, Nutrition, Meal Preferences and Experiences Among Elderly A Literature Overview From a Scandinavian Context
}

\author{
Maria Nyberg ${ }^{1}$, Viktoria Olsson ${ }^{1}$, Zada Pajalic ${ }^{2,3}$, Gerd Örtman $^{2}$, Håkan S. Andersson ${ }^{2}$, Anna Blücher ${ }^{2}$, \\ Karin Wendin ${ }^{1,5}$ \& Albert Westergren ${ }^{4}$ \\ ${ }^{1}$ Food and Meal Science, School of Learning and Environment, Kristianstad University, Sweden \\ ${ }^{2}$ Department of Chemistry and Biomedical Sciences, Linnaeus University, Kalmar, Sweden \\ ${ }^{3}$ Oslo and Akershus University, Norway \\ ${ }^{4}$ The PRO-CARE group, School of Health and Society, Kristianstad University, Sweden \\ ${ }^{5}$ SP Technical Research Institute of Sweden, Lund, Sweden \\ Correspondence: Maria Nyberg, Food and Meal Science, School of Learning and Environment, Kristianstad \\ University, Sweden. Elmetorpsvägen 15, SE-291 88 Kristianstad, Sweden. Tel: 46-44-203-818. E-mail: \\ maria.nyberg@hkr.se
}

Received: September 12, 2014 Accepted: October 8, 2014 Online Published: October 10, 2014

doi:10.5539/jfr.v4n1p22 URL: http://dx.doi.org/10.5539/jfr.v4n1p22

\begin{abstract}
The risk of malnutrition increases with ageing, resulting in poorer health and higher risk of disease. Eating difficulties are important risk factors for malnutrition. Moreover, independence in relation to food and meals is highly rated by the elderly and has been associated with health and well-being. The purpose of this literature overview was to provide insights into nutritional status, food choice and preferences as well as the meal situations of home-living elderly $(65+)$ people with motoric eating difficulties focusing on Scandinavia. The overall aim is to support independence and to prevent malnutrition. Nutritional status in the elderly was found to be negatively influenced by motoric eating difficulties including problems with manipulating food on the plate and transporting food to the mouth. Motoric eating difficulties may result in practical simplifications such as use of pre-prepared meals, less advanced cooking, and omission of certain meal constituents in order to avoid e.g. mismanagement and spillage. Eating difficulties are often accompanied by feelings of guilt and shame. Choosing smaller portions, reducing the number of eating episodes and not cooking independently have been associated with a higher risk of malnutrition. The nutritional effects of eating difficulties may be exacerbated by diminished chemosensory functions. Furthermore, both past and present food preferences should be considered in order to meet nutritional needs and meal satisfaction. Development of refined and socially accepted eating aids, in combination with tasty and nutritious products, is important in order to promote healthy and independent living among home-living elderly with motoric eating difficulties.
\end{abstract}

Keywords: eating difficulties, elderly, food choice, malnutrition, meal situation, nutritional status

\section{Introduction}

A growing elderly population is a reality in all welfare states. The risks of ailment and malnutrition, manifested as impaired body function and a higher prevalence of morbidity, increase with ageing. According to Statistics Sweden (SCB) the proportion of elderly people ( $>65$ years) in the population is expected to increase to $25 \%$ in 2060 (SCB, 2014). Nowadays, approximately 250000 elderly persons in Sweden are in need of help with their meals in everyday life (Bülow et al., 2007). Besides, many elderly people are being cared at home (Mattsson Sydner \& Fjellström, 2007). This indicates a need for new approaches to prevent related complications, such as malnutrition, social isolation, decreased quality of life and greater pressure on the health service and elderly care sector. Eating difficulties are important risk factors for malnutrition (Westergren, Karlsson, Andersson, Ohlsson, \& Hallberg, 2001; Westergren, Lindholm, Mattsson, \& Ulander, 2009). Westergren and Karlsson et al. (2001) define eating difficulties as "difficulties that, alone or in combination, negatively interfere with the preparation and intake of served food and/or beverages" (p. 258). Eating difficulties may be a result of specific diseases, 
such as Parkinson's disease, stroke or rheumatoid arthritis (Jacobsson, Axelsson, Österlind, \& Norberg, 2000), but may also be due to the ageing process as such. Much of the research on eating difficulties has focused on dysphagia (Westergren, Unosson, Ohlsson, Lorefält, \& Hallberg, 2002). However, a wide spectrum of eating difficulties exists. Leopold and Kagel (1997) defined a five-stage "ingestion paradigm" including the pre-oral (anticipatory), preparatory, lingual (oral), pharyngeal and oesophageal phases (Leopold \& Kagel, 1997). Motoric eating difficulties primarily affect the pre-oral phase and include problems such as manipulating food on the plate and transporting food to the mouth (Jacobsson et al., 2000; Westergren, Lindholm et al., 2009). Possible causes could be tremors, weaknesses such as problems with gripping and/or lifting the arm and hand, or involuntarily arm movements. This may also lead to problems associated with putting food on the plate, holding the plate when food is served, peeling fruits and vegetables, as well as setting and clearing the table. Reported difficulties in chewing, self-feeding, shopping for basic necessities, carrying a shopping bag, cooking a meal and using fingers to grasp or hold increase the risk of an inadequate energy intake (Bartali et al., 2003). Eating difficulties may also affect food choice, the amount and variety of food (Sidenvall, Fjellström, \& Ek, 1994; Lorefält, Ganowiak, Wissing, Granerus, \& Unosson, 2006) as well as the social context of the meal and the meal experience (Gustafsson, Andersson, Andersson, Fjellström, \& Sidenvall, 2003).

The primary purpose of this literature overview is to highlight the nutritional status, food choice and preferences as well as the meal situation of home-living elderly $(65+)$ people with motoric eating difficulties, specifically focusing on problems in transporting food from the plate to the mouth. It is our conviction that knowledge of such limitations is a prerequisite for the efficient development of new and refined eating aids as well as food and meal products, which can support the elderly in healthy and independent living.

\subsection{Search Strategies}

The literature overview is primarily based on Scandinavian studies, although international articles are used to illustrate more general problems and perspectives in relation to the subject in question. Scientific databases, including PubMed, Web of Science, Science Direct and Sociological Abstracts, have been searched from 1990 onwards, for articles including home-living elderly people, aged 65 and over. Search terms used were 'elderly, eating difficulties, nutritional status, malnutrition, food preference, food choice, taste, meals, social eating'. 'Elderly' and 'eating difficulties' combined has been the main discriminating term, subsequently coupled to the other search terms in order to find relevant articles dealing with elderly with eating difficulties from different perspectives. Furthermore, the reference lists of relevant articles were hand searched, with resulting studies assessed for relevance, and have been included in the overview.

\section{Nutrition Status in the Elderly}

The elderly is a heterogeneous group in many aspects. According to the World Health Organisation (WHO) definition, people over 60 years of age are included in this group (WHO, 2002). However, with increasing longevity some countries define separate groups of oldest people. Previous research has made a division of chronological age into younger old (65-74), old/mid-old (75-84) and oldest old (85+) (B. Given \& W. Given, 1989). A similar definition has been stated by Field and Minkler (1988) as follows: young old (60-74), old old (75-84) and very old (85+). Many people 65 years and over are healthy and independent. However, a large number of elderly people, especially those 85 years and over, are in need of assistance and health care (Bülow et al., 2007; Daunfeldt, Gustafsson, Hortlund, \& Rosén, 2009). Higher age is associated with higher risk of disease, frailty, functional disabilities, including various eating difficulties, as well as sensory losses (McLaren \& Dickerson, 2000; Westergren et al., 2002; Johansson, Sidenvall, Malmberg, \& Christensson, 2009; Rasheed \& Woods, 2013). Therefore, proper nutrition is important in order to maintain good health. However, energy and nutrient requirements vary over life. Ageing and specific diseases may reduce appetite whilst the need for energy and nutrients increases. Many elderly people, especially late elderly, have difficulties meeting their basic requirements for energy and nutrients, in particular protein and vitamin D. Studies have indicated low protein intake among the elderly and frail elderly living at home (Tieland, Borgonjen-Van den Berg, van Loon, \& de Groot, 2012; Westergren, Hagell, \& Sjodahl Hammarlund, 2014). Ageing and associated physiological and psychological changes therefore increases the risk of malnutrition. Malnutrition may include overweight/obesity as well as underweight (Westergren et al., 2014) and has been defined as "a state of nutrition in which deficiency or excess (or imbalance) of energy, protein, and other nutrients causes measurable adverse effects on tissue/body form (body shape, size and composition) and function, and clinical outcome" (Lochs et al., 2006, p. 182). On the other hand, the term undernutrition is primarily used "in the context of deficient energy or protein intake or absorption (...)" (Lochs et al., 2006, p. 182). The causes of malnutrition are complex and often diverse, and may be both the cause and the result of specific diseases, and a consequence of insufficient food intake. In this overview, malnutrition is primarily used in the context of undernourishment as a result of eating difficulties. 
With an increased number of elderly people living in their own homes, with or without food delivery and/or home care, the exact number of people with malnutrition or at risk of malnutrition, is difficult to estimate. In studies by Russel and Elia $(2008,2010,2012)$ the prevalence of malnutrition in the UK was estimated to be $28-42 \%$ among elderly people who had recently moved to a care home or been admitted to hospital. In Sweden, studies have found that malnutrition occurs in about $30 \%$ of all cases of elderly people moving from their own homes to service housing (Christensson, Unosson, \& Ek, 1999; Wikby, Ek, \& Christensson, 2006; Saletti, 2007). Prevalence of malnutrition in Scandinavia is further presented in Table 1.

Table 1. Examples of studies presenting prevalence figures of undernutrition/malnutrition risk in different Scandinavian countries and settings

\begin{tabular}{|c|c|c|c|c|c|}
\hline Setting & $\mathbf{n}$ & $\begin{array}{l}\text { Nutrition } \\
\text { risk, \% }\end{array}$ & $\begin{array}{l}\text { Screening } \\
\text { methods }\end{array}$ & Comments & References \\
\hline \multicolumn{6}{|l|}{ Hospitals } \\
\hline Denmark & 590 & 40 & NRS 2002 & Hospitals with $>200$ beds & $\begin{array}{l}\text { Rasmussen et al. } \\
2004\end{array}$ \\
\hline Norway & 3279 & 29 & NRS 2002 & $\begin{array}{l}\text { University hospital ( } 975 \\
\text { beds). Data collected } \\
\text { 2008-2009 }\end{array}$ & $\begin{array}{l}\text { Tangvik et al. } \\
2014\end{array}$ \\
\hline Sweden & & & MEONF-I & & $\begin{array}{l}\text { Westergren, } \\
\text { Wann Hansson } \\
\text { et al. } 2009\end{array}$ \\
\hline Large ( $>500$ beds) & 1197 & 34 & & Eating difficulties: $58 \%$ & \\
\hline Middle (200-500 beds) & 824 & 26 & & Eating difficulties: $50 \%$ & \\
\hline Small (<200 beds) & 370 & 22 & & Eating difficulties: $42 \%$ & \\
\hline \multicolumn{6}{|l|}{ Nursing homes } \\
\hline Denmark & 180 & 33 & $\mathrm{BMI}<20$ & & Beck et al. 2002 \\
\hline Norway & 164 & 33 & MUST & Persons with dementia & $\begin{array}{l}\text { Aukner et al. } \\
2013\end{array}$ \\
\hline Sweden & & & MEONF-I & & $\begin{array}{l}\text { Westergren \& } \\
\text { Hedin, } 2010\end{array}$ \\
\hline Year 2005 & 1726 & 26 & & Eating difficulties: $53 \%$ & \\
\hline Year 2007 & 1526 & 30 & & Eating difficulties: $52 \%$ & \\
\hline Year 2009 & 1459 & 26 & & Eating difficulties: $53 \%$ & \\
\hline \multicolumn{6}{|l|}{$\begin{array}{l}\text { Ordinary living with } \\
\text { home-care/service }\end{array}$} \\
\hline Denmark & 200 & 30 & $\mathrm{BMI}<20$ & & Beck et al. 2002 \\
\hline Norway & 194 & 33 & MUST & Persons with dementia & $\begin{array}{l}\text { Aukner et al. } \\
2013\end{array}$ \\
\hline Sweden & 579 & 14.5 & MNA & $\begin{array}{l}\text { Mix of with/without } \\
\text { home-care/service }\end{array}$ & $\begin{array}{l}\text { Johansson et al. } \\
2008\end{array}$ \\
\hline \multicolumn{6}{|l|}{$\begin{array}{l}\text { Ordinary living } \\
\text { without } \\
\text { home-care/service }\end{array}$} \\
\hline \multirow[t]{2}{*}{ Sweden } & 465 & $\begin{array}{l}35 \\
\text { (moderate } \\
\text { risk) }\end{array}$ & SCREEN-II & $\begin{array}{l}\text { Malnutrition risk } \\
\text { (including undernutrition } \\
\text { risk) }\end{array}$ & $\begin{array}{l}\text { Westergren et al. } \\
2014\end{array}$ \\
\hline & & $\begin{array}{l}30 \text { (high } \\
\text { risk) }\end{array}$ & & & \\
\hline
\end{tabular}

Note: NRS 2002= Nutritional Risk Screening 2002; MEONF-I= Minimal Eating Observation and Nutrition Form - Version I; BMI= Body Mass Index; MUST= Malnutrition Universal Screening Tool; MNA= Mini Nutritional Assessment; SCREEN-II= Seniors in the Community: Risk Evaluation for Eating and Nutrition Version II. 
In a study by Soini, Routasalo and Lauri (2006), half of the patients living at home and receiving home care in Finland were at risk of malnutrition and 3\% were malnourished. About one third of the participants living at home and receiving home care did not have a balanced diet. All of those who were malnourished lived alone. Other studies have shown that those with poor nutritional status and dependent on Activities of Daily Living (ADL), were often in greater need of help with food intake (Carlsson, Haglin, Rosendahl, \& Gustafson, 2013). Therefore, home care for the elderly is recommended as one way of preventing malnutrition (Lundin, Lundin, Sääf, Strender, \& Mollasaraie, 2012).

Malnutrition with or without chronic disease may be the primary factor limiting both the mental or physical function of home-living elderly individuals (Kondrup, Allison, Elia, Vellas, \& Plauth, 2003). Early detection of malnutrition is therefore of great importance (Westergren et al., 2002; Guigoz, 2006). Successful actions have been taken in the past 15 years to prevent and treat malnutrition and these have also shown that nutritional care is important (Westergren, Axelsson, et al., 2009; Törmä, Winblad, Cederholm, \& Saletti, 2013). Screening of nutritional status and identifying what may be associated with nutritional problems, have proven to be useful interventions in preventing malnutrition (Westergren, Norberg, \& Hagell, 2011; Söderhamn, Dale, Sundsli, \& Söderhamn, 2012; Söderström et al., 2013). During recent years, new and improved screening methods have been developed. The Mini Nutritional Assessment (MNA), SCREEN II, NUFFE-NO and MEONF-II, among others, have been shown to be useful tools in identifying the need for nutrition intervention (Guigoz, 2006; Keller, 2006; Wikby, Ek, \& Christensson, 2008; Vallén, Hagell, \& Westergren, 2011; Westergren, Norberg, \& Hagell, 2011; Westergren, Norberg, Vallén, \& Hagell, 2011; Söderhamn et al., 2012). Nutritional assessment typically involves a weighted assessment of body weight, weight history and reporting of any eating difficulties. Body Mass Index (BMI) measurement has also been employed to assess nutritional status and to detect malnutrition, but its usefulness among those older than 70 years has been debated (Westergren, Lindholm, Axelsson, \& Ulander, 2008). Active self-care and the overall attitudes of the elderly to nutrition is also of great importance in preventing malnutrition (Backman \& Hentinen, 1999). For instance, study circles have been used to stimulate the awareness and knowledge of both staff and the elderly about self-care and how to reduce the risk of malnutrition (Westergren, Axelsson, et al., 2009).

\section{Nutrition and Eating Difficulties}

Eating difficulties caused by problems in manipulating food on the plate, transporting food to the mouth and problems with chewing and swallowing (dysphagia) are described as important causes of malnutrition or risk factors for malnutrition (Westergren, Karlsson, et al., 2001; Westergren, Ohlsson, \& Hallberg, 2001; Ekberg, Hamdy, Woisard, Wuttge-Hannig, \& Ortega, 2002; Westergren et al., 2002; Bülow et al., 2007; Maitre, Van Wymelbeke, Amand, \& Vigneau, 2014). In her doctoral work, Saletti (2007) investigated the nutritional status of 1305 elderly people in Sweden (mean age 85 years, $73 \%$ women). It was found that approximately a quarter of the population was malnourished and almost half of the population were found to be at risk of malnutrition. Problems with chewing and swallowing, reduced appetite as well as illness and depression, were more frequent among those who were malnourished.

Diseases such as Parkinson's disease, stroke and rheumatoid arthritis are often associated with eating difficulties (Jacobsson et al., 2000; Lorefält, Ganowiak, et al., 2006). Symptoms that affect nutrient intake and nutritional uptake in people with Parkinson's disease include stiffness, tremors, slow body movements, swallowing difficulties, and decreased motility of the gastrointestinal tract. Parkinson's disease is also energy-consuming due to the symptoms mentioned above (Lorefält, Ganowiak, et al., 2006). Rheumatoid arthritis often leads to distorted joints, which may result in difficulties with lifting pots and pans, and gripping a knife and fork (Nordenskiöld, 1997). Elderly people with low handgrip strength who are living at home are also at risk of malnutrition (Johansson, Bachrach-Lindström, Carstensen, \& Ek, 2008). Help from relatives and partners is well-known to reduce this risk. For instance, in a study by Andersson and Sidenvall (2001), women suffering from Parkinson's disease who lived alone exhibited a greater risk of developing nutritional problems in comparison with married women, who could get help from their partners.

Moreover, people who have suffered a stroke also frequently have difficulties concerning food ingestion, swallowing and, as a consequence, energy deficiency (González-Fernández, Ottenstein, Atanelov, \& Christian, 2013). As many types of eating problems tend to occur concurrently in these individuals, the risk of malnutrition is imminent (Westergren, Karlsson, et al., 2001; Westergren, Ohlsson, et al., 2001; Ekberg et al., 2002). Westergren and Karlsson et al. (2001) found that $80 \%$ of the patients exhibited eating difficulties after a stroke pertaining to: 1) eating three-quarters or less of the food served, 2) difficulties manipulating food on the plate, 3) transport of food to the mouth, 4) sitting position, 5) aberrant eating speed, 6) manipulating food in the mouth 7) swallowing difficulties, 8) opening and/or closing the mouth, and 9) alertness. Kumlien and Axelsson (2002) 
showed that the majority of stroke patients living in nursing homes required some kind of help with eating, due to swallowing problems, pneumonia, forgetting to eat and poor appetite. The help needed was described as feeding assistance, adjustment of food and liquid consistencies, cutting up the food as well as supervision of the eating process.

Managing the nutritional needs of elderly people with eating difficulties and multiple diagnoses requires cooperation between different professions. In Sweden, Johansson et al. (2006) observed unclear division of responsibilities between professional groups, deficiencies in organisations and procedures, lack of adequate training with regard to clinical nutrition, as well as a low interest in the field. The problem of malnutrition is frequently underestimated and nurses often lack both an overview and knowledge of the nutritional perspective.

The underlying causes of malnutrition therefore vary among home-living elderly individuals with eating difficulties and it follows that the nutritional needs among this group may differ. Generally, energy requirements are reduced as compared to more active, younger or middle-aged persons, while the need for nutrients is either unchanged or increased, such as for protein and vitamin D (Westergren et al., 2014). Frail elderly people with multiple diagnoses should consume a higher proportion of their total energy intake from protein (Bauer et al., 2013). Moreover, the lipid quality should be optimized in a diet where food is served more frequently in small portions. It is also important that the consistency and sensory quality of food meet the needs and preferences of the individual.

\section{Food Choice and Preferences in the Elderly}

\subsection{Food Preferences Are Influenced by Previous Experiences and Impaired Chemosensory Capabilities}

Meals provided to home-living elderly people need to be of high quality i.e. safe, nutritious and adapted to the individual needs of the elderly. Past experiences of food during childhood and earlier adulthood may impact attitudes concerning food and meals in later life (Edfors \& Westergren, 2012). The foundations of norms and values regarding food culture, traditions and eating habits are laid early (Edfors \& Westergren, 2012). However, food choice is not static and may change during the course of life so that the eating habits of an individual may not be the same in early adulthood as they are in later life (Mattsson Sydner, 2002; Irz et al., 2014). These changes over time also create variations in food habits between different generations, both with regard to food choice as such, as well as with regard to how the meal as a whole is constructed (Mattsson Sydner, 2002). Furthermore, as stated earlier, the elderly is a very heterogeneous group with large general and individual variations regarding food choice and preferences. For example, it has been shown that in 70 year-olds, selection of food varies by education and occupational status while socio-economic disparities in diet quality were observed in men only (Cabrera et al., 2006). Maintenance of a healthy diet is one of the most important factors affecting food choice among older consumers and eating healthy can be regarded as an investment to ensure independency (Lundkvist, Fjellström, Sidenvall, Lumbers, \& Raats, 2010). Insufficient resources are however, according to Irz et al. (2014), not a driver for poor dietary choices in Sweden and Finland. Thus, there is no common diet that suits the needs and wishes of all elderly people but a few recent studies indicate some general features that can be attributed to food for the elderly from a cultural and geographic context.

In the study by Edfors and Westergren (2012), elderly people in Sweden described how home-cooked dishes made from locally produced ingredients were a common part of the diet when they were growing up. According to some of the respondents, meals in their early adulthood could typically consist of porridge, wholemeal bread, potatoes, pork, and fresh fish. At ceremonies and celebrations, freshly slaughtered meat and more luxurious food might have been offered. Furthermore, the diet was often based on seasonal availability and it was vital to "make do with what the house could offer" and to seize every opportunity to increase the food supply by, for instance, hunting, fishing, and picking berries (Edfors \& Westergren, 2012). Today's elderly are often used to cooking for themselves and they appreciate a difference between everyday meals and special occasions.

For home-living elderly people who are provided with food, trust in the food is an important aspect. Central components of this trust are, amongst others, transparency and recognition. Transparency includes the elderly person's possibility to know or be able to find out important food-traits like the type of ingredients, cooking methods and transportation used. Recognition of food is connected to the person's own experiences of food. The type of food that the elderly person has eaten and been confronted with during life has resulted in experiences that are important to the individual and the elderly person knows from these experiences what can be considered as tasty, nutritious and healthy food (Bergh, 2005). Indeed, the influence of previous experiences on food acceptability is very important at any age (Giacalone, Duerlund, Bøegh-Petersen, Bredie, \& Frøst, 2014). Cultural identity is thus manifested in the choice and use of food and beverages. If the food offered is unknown to the elderly, if a well-known dish has a new and unfamiliar name or if it tastes or smells differently, this may 
affect the trust negatively (Bergh, 2005). If a home-living elderly person is served meals that he or she cannot identify with, it may lead to impaired quality of life. The core issue is the possibility to - although old and frail remain the person you are and in that respect, the food that is served and eaten is central.

For older women and men, the meaning of healthy eating has previously been shown to be identical to the notion of "a proper meal", including meat or fish, potatoes and vegetables (Rothenberg, Bosaeus, \& Steen, 1994; McKie, MacInnes, Hendry, Donald, \& Peace, 2000). Mattsson Sydner and co-workers described that elderly people often have a general preference for food that is easy to digest (Mattsson Sydner, Sidenvall, Fjellström, Raats, \& Lumbers, 2007). Further, according to the findings of Edfors and Westergren (2012), foods that contained unfamiliar spices and were too influenced by modern food trends were not appreciated. The elderly requested more varied old-fashioned food, cooked in the traditional way with well-known spices such as salt, pepper, dill, and bay leaves. In an interview-investigation by Weurlander and Gurner (2006) some informants expressed a desire for dishes based on, amongst other things, salmon, chicken, herring, pea-soup, freshly made pancakes, fermented luncheon-sausage (isterband) and new potatoes. The view of elderly as being relatively conservative consumers was further supported in a Finnish study where elderly (66-80 years) proved to be more neophobic than other age groups (Tuorila, Lähteenmäki, Pohjalainen, \& Lotti, 2001). However, today there may be a greater tolerance among the elderly to new culinary sensations and, as an example, in a study by Johansson (2013) staff expressed that some people in elderly care liked trying new tastes. Evidently, what is a preference for one generation might not be the same for another generation.

Another factor to consider regarding food preferences of the elderly is the well-known fact that appetite, smell, taste and eye-sight often decrease with age and these impairments may be exacerbated by illness or medication (Engelheart, Lammes, \& Akner, 2005; Nordin et al., 2007; Methven, Allen, Withers, \& Gosney, 2012). For example, people with Parkinson's disease often have a specifically reduced sense of taste and smell (Andersson \& Sidenvall, 2001). Sensory losses may partly be overcome by using, for example, distinct flavours and presentation (Rothenberg et al., 2007; Hall \& Wendin, 2008). If, on the other hand, the food is monochromatic and mixed together, the meal may be rejected. There is not always a clear connection between enhanced flavour and perceived pleasantness or intake. The addition of different types of flavour enhancers has in some studies resulted in an increased liking, and by extension, increased intake of the food that is served, e.g. Schiffman (1998), while in other studies, e.g. Koskinen, Kälviäinen and Tuorila (2003), this effect has not been observed. Wylie and Nebauer (2011) emphasize that flavour enhancers related to life-long preferences of older people should be considered. In a Swedish context, natural enhancers like pickled herring, anchovy and "ättika" (vinegar), all characteristic for the traditional cuisine, are appreciated among elderly and used as a way to stimulate appetite and food intake.

In a perceptive system where taste and smell have lost part of their significance, the roles of other factors in the meal experience become more important, and texture may sometimes surpass taste in importance, particularly in bland food (Elsner, 2002). As an example, presence of peel or seeds and hard and fibrous textures in fresh fruit and vegetables may make them difficult to prepare and messy to eat according to elderly (Roininen, Fillion, Kilcast, \& Lähteenmäki, 2004) and texture-modification may be of importance in preventing malnutrition (Rothenberg et al., 2007) also for those with motoric eating difficulties. By combining sensory and consumer studies it is possible to optimize texture and product quality to meet the needs and demands of older people (Hall $\&$ Wendin, 2008). The development of food and meals that are well accepted among elderly therefore requires better knowledge to what extent the individual can perceive chemosensory stimuli, better knowledge on how to compose dishes with high and distinct flavours and adapted textures, and on how to choose and administer different types of flavor enhancers.

\subsection{Do Eating Difficulties Affect Food Choice and Preferences?}

Negative life events affect food and meals in present life (Edfors \& Westergren, 2012; Maitre et al., 2014) and eating options are consequently limited. One example may be the onset of eating difficulties like motor symptoms in the upper extremities, tremor, pronation/supination and handgrip. These impairments may result in inconsistent effects within the lives of individuals and diverse strategies to overcome motoric eating difficulties may be employed, including the use of various eating aids. By using familiar dishes, food and drinks, the memories of smell or taste can be re-created. This can be important in enhancing the meal experience among elderly people suffering from e.g. Parkinson's disease (Andersson \& Sidenvall, 2001). In geriatric care settings, studies show that elderly people varied in acceptance of their limitations with regard to eating difficulties but that they all described using strategies to minimise conspicuousness and maintain dignity (Sidenvall \& Fjellstrom, 1994; Sidenvall, Fjellström, \& Ek, 1996). 
Not many Scandinavian studies focus on how the food choices of home-living elderly people are influenced by motoric eating difficulties. In early studies in a geriatric care setting, Sidenvall et al. $(1994,1996)$ showed how shortcuts were taken and meal constituents omitted to avoid mismanagement, spillage or inappropriate behavior due to motoric eating difficulties. Aids and adaptations were only accepted by those wholly dependent upon them; others strove to manage without. Later, Andersson and Sidenvall (2001) described that women with Parkinson's disease find it easier to eat soft food with the help of a spoon when motor symptoms in the upper extremities are exacerbated. Eating solid food, by contrast, requires a certain degree of strength and adequate hand motility to manage a knife and fork. Similar problems have been described in other disabling diseases (Westergren et al. 2002). A decrease in intake of solid food may result in less consumption of fresh fruit and vegetables, which could lead to a deficiency e.g. of certain vitamins (Lorefält, Ganowiak et al., 2006).

Convenience foods, such as precooked frozen dishes and full meals, are sometimes chosen by frail elderly who do not have enough strength to cook the main meal themselves (Edfors \& Westergren, 2012). Prepared dishes may be considered easier to cook, for example, in a microwave, a cheaper alternative and sometimes better tasting than the food served at the municipality's elderly day care centre (Edfors \& Westergren, 2012). The option to choose and buy prepared dishes may also be perceived as a freedom, as compared to receiving meals-on-wheels, although as a permanent solution this is not without difficulties (Andersson \& Sidenvall, 2001). Foods that are documented as problematic for persons with motoric eating difficulties include bread in loaves that has to be cut and buttered (Andersson \& Sidenvall, 2001) as well as the presence of peel or seeds, and hard and fibrous textures in vegetables, which resulted in difficulties with regard to their preparation (Roininen, Fillion, Kilcast, \& Lähteenmäki, 2004). At least two studies have shown that milk may be an important food item to compensate for insufficient energy intake, as it can be conveniently consumed at any time and is indeed commonly used by disabled women (Andersson, Nydahl, Gustafsson, Sidenvall, \& Fjellström, 2003; Lorefält, Unosson, \& Granerus, 2006).

Impaired arm mobility may have a negative impact on the intakes of protein and energy (McLaren \& Dickerson, 2000 ) and, as described above, motoric eating difficulties may be part of a multifaceted explanation for weight loss in Parkinson patients (Lorefält, Ganowiak, et al., 2006; Lorefält, Unosson, et al., 2006). Lorefält, Ganowiak et al. (2006) point at specific food items, like fruit and vegetables that were in some cases omitted from the menu. Furthermore, elderly people with Parkinson's disease also tended to eat less regularly and consumed fewer prepared meals (Lorefält, Ganowiak, et al., 2006). Swedish studies have demonstrated that men living alone and diagnosed with Parkinson's disease, stroke or rheumatoid arthritis, were more at risk of malnutrition due to having fewer eating events per day and more seldom cooking their meals from raw ingredients (Kullberg, Aberg, Bjorklund, Ekblad, \& Sidenvall, 2008; Kullberg, Björklund, Sidenvall, \& Åberg, 2011). In the study by Söderström et al. (2013), few eating episodes and not cooking independently were associated with a higher risk of developing malnutrition. According to one study, functional impairments limiting food-related activities does not, however, have an independent effect on the regularity of meals (Kallio, Koskinen, \& Prättälä, 2008) but the authors emphasize that help in carrying out food-related activities contributes to maintenance of a conventional meal pattern, especially important in lower socio-economic groups. Overall, this advocates the use of smaller, regularly administered meals with a high nutritional value for elderly people with motoric eating difficulties; it also indicates that hot meals are important in the overall energy intake of the elderly. Prepared meals usually contain more energy and nutrition than snacks do. Therefore, following the meal pattern that can be defined here as conventional in the Nordic countries - breakfast and two hot meals - might be an important factor contributing to maintaining a good nutritional status among the elderly (Kallio, Koskinen, \& Prättälä, 2008).

\section{Meal Situation}

\subsection{Eating Difficulties and Experiences of the Eating Situation}

Food is not only nutrients, energy or specific food items that are combined to produce certain dishes with various textures and flavours. Food is also part of larger social and cultural contexts. Distinct cultural norms surround eating; everything from selecting food, how to prepare it, when and together with whom, to the actual act of eating, and how and when to put food into the mouth. With eating difficulties, these norms, rules and values are frequently challenged and may be difficult to live up to. Food and meals are often described as important social events (Fjellström, Sidenvall, \& Nydahl, 2001; Fjellström, 2009), even though older people commonly eat their meals with fewer people present compared to younger people (de Castro, 2002). However, being elderly and having eating difficulties may change the value and meaning of the meal as a social event. People with eating difficulties often experience feelings of guilt, shame and disappointments (Jacobsson et al., 2000; Carlsson, Ehrenberg, \& Ehnfors, 2004; Fjellström, 2009; Medin, Larson, von Arbin, \& Wredling, 2010). Ekberg et al. (2002) stated that meals should be pleasurable experiences. However, in their study the elderly participants with 
eating difficulties described feelings of anxiety and panic during meals and avoided eating with others. Problems with slow eating speed as a result of eating difficulties are also described (Andersson \& Sidenvall, 2001; Gustafsson et al., 2003; Medin, Larson, von Arbin, \& Wredling, 2010). Large portions of food often became cold before the meal was completed. To avoid this, smaller portions were an alternative, with the risk of malnutrition as a consequence (Gustafsson et al., 2003). Social and cultural norms surrounding the meal may be perceived as an obstacle to eating with others in a social context (Jacobsson et al., 2000). Social withdrawal has been described as a strategy to manage the eating situation when social and cultural codes are unable to be followed (Gustafsson et al., 2003). Although there is no entirely clear link between eating alone and malnutrition, the experience of meals eaten alone, especially among women, is often described as less satisfying (Shahar, Schultz, Shahar, \& Wing, 2001; Fjellström \& Mattsson Sydner, 2009). However, people suffering from eating difficulties may sometimes benefit nutritionally from eating alone.

Men and women tend to experience food and eating in relation to physical restrictions in different ways. Many studies in Scandinavia of food and the elderly concentrate on the perspectives of women (Fjellström \& Mattsson Sydner, 2009). Older women often relate to food as something central to their identity (Gustafsson \& Sidenvall, 2002) and being able to cook food is considered an important and natural part of daily life. Sidenvall et al. (2000) describe how the planning and preparation of food and meals for family and friends, as well as enjoying the meal together, were natural parts of their feelings of well-being (Sidenvall, Nydahl, \& Fjellström, 2000). The meal is described as a gift and it gives the older women increased self-esteem to be able to provide a meal (Sidenvall, Nydahl, \& Fjellström, 2001) Losing a partner and living alone may affect food intake as well as attitudes to food and meals negatively. However, men seem to adapt more functionally to having to eat by themselves, and they are also more content with eating alone (Edfors \& Westergren, 2012). Studies have indicated that more men eat to satisfy their hunger, without investing energy in the social aspects to the same extent as women (Sidenvall et al., 2000; Fjellström et al., 2001). Women's lack of meaning and motivation to cook for themselves and men's inability and lack of knowledge to cook when becoming widowers, increase the risk for malnutrition among elderly people living in their own homes. Accordingly, Westergren et al. (2014) found that an increased risk of malnutrition among home living elderly people in Sweden was associated with being a woman living alone (Odds Ratio (OR) 4.63) or a man living alone (OR 6.23).

\subsection{Independence as a Primary Goal}

There is great research support for the notion that elderly people want to be independent for as long as possible (Strandberg, 2002; Berg, Sarvimäki, \& Hedelin, 2006; Fjellström, 2009). Being independent and being able to eat and cook for yourself, are strongly associated with well-being and increased self-esteem (Gustafsson et al., 2003; Fjellström, 2009). Hope of recovery is often associated with the ability to eat independently (Jacobsson et al., 2000). In the Norwegian study, health and "being able to" were clearly linked to each other (Berg et al., 2006). Sidenvall et al. (2001) descried how the eating, cooking and purchase of food become concrete expressions of independence in everyday life, and these activities become symbols of continuity. Therefore, understanding the meaning of food, as well as the activities which food is part of, are important (Mattsson Sydner \& Fjellström, 2006).

The experience of self-determination, freedom and autonomy are described as important for elderly people (Edfors \& Westergren, 2012; Pajalic, 2013), also in relation to decisions about the purchase of food, food choice and meals. In another study, independence and integrity have also been described as positively associated with appetite, where being dependent had the opposite effect (Wikby \& Fägerskiöld, 2004). This is in agreement with the systematic review conducted by Rasheed and Woods (2013), which indicates that individuals suffering from malnutrition, partly as a result of poor appetite, are also more likely to experience poor quality of life. Independence and "not being a burden" in relation to food and meals are described as central driving forces (Lundkvist, Fjellström, Sidenvall, Lumbers, \& Raats, 2010). The importance of eating independently is specifically noticed in studies of people suffering from certain diseases that affect the eating process. In a study among elderly women with Parkinson's disease, the importance of independence was emphasised, even if the disease made them accept help to a certain extent. Difficulties in maintaining independence were most pronounced for women living alone (Andersson \& Sidenvall, 2001). In another study, participants with eating difficulties expressed fear of being dependent (Gustafsson et al., 2003). Striving to live "a normal life" was emphasised, which includes being independent in relation to food and meals. For those with rheumatoid arthritis, problems with lifting things or grabbing plates from kitchen shelves, lifting heavy pots or casseroles and cutting food on the plate could be a great obstacle to independence. However, the women participating in the study had their own ways of managing the situation. Special scissors allowed them to open milk packages easily and to cut 
food on the plate. Carrots could be eaten cooked instead of grated. Thus, independence could be maintained through creativity in adaptation and simplification of cooking methods.

Although independence is highly valued, many people with eating difficulties need help from other people sooner or later in order to manage their eating situation (Fennell, Phillipson, \& Evers, 1988; Hockey \& James, 1993). The home-delivered meal has been described as a symbol of dependency even for those without specific eating difficulties (Pajalic, Persson, Westergren, Berggren, \& Skovdahl, 2012). Various life events, for example the passing away of one's partner, may lead to elderly people moving from independence to dependence (Edfors \& Westergren, 2012). Illness is another example, which may also influence gender roles concerning food, making the wife the "food-receiver" and the husband the "food-giver" (Fjellström, 2009). In a study of stroke patients, negative feelings of dependency as well as feelings of abandonment and loss, were described by those having eating difficulties as a result of their stroke (Carlsson et al., 2004). Feelings of dependency were obvious during the meals, where risks of spilling, coughing and not being able to manipulate the food on the plate were reported. Two types of losses were described: the loss of function in relation to eating and the loss of the possibility to perform certain activities in relation to food and eating. In another study by Jacobsson et al. (2000), the problem of asking for help was further described, as well as the difficulties of dealing with feelings of clumsiness and uncertainty. Medin, Larsson, von Arbin, Wredling and Tham (2010) also described the difficulties concerned with receiving help from others, such as unknown people cutting the food on the plate and having to be fed by others. Lack of control regarding speed and rhythm was extremely troublesome, as well as obtaining appropriate sized pieces of food (Medin, Larson, von Arbin, Wredling, \& Tham, 2010). Being fed has been associated with feelings of humiliation (Jacobsson et al., 2000).

\subsection{Managing the Meal Situation}

Different strategies to manage the eating situation are described by home-living elderly people with motoric eating difficulties. Common strategies to maintain independence were, for example, simplifying cooking and eating, and eating more cold meals and snacks (Andersson \& Sidenvall, 2001; Gustafsson \& Sidenvall, 2002; Mattsson Sydner et al., 2007; Lundkvist et al., 2010). Fewer cooked meals and more cold meals and snack-events with coffee and cake have also been described as frequent in other studies, especially among elderly people living alone (Sidenvall et al., 2001; Edfors \& Westergren, 2012). Those who lived with a partner more often described how they ate "proper meals" (Gustafsson \& Sidenvall, 2002). "Less elaborate meals" have been described as a result of having specific eating difficulties, but also as a result of loss of appetite, frailty and loneliness (Mattsson Sydner et al., 2007).

Lowering ambitions and using familiar products, ingredients and dishes are also common strategies employed to maintain independence (Sidenvall et al., 2001; Gustafsson et al., 2003). Cooking something new can be exhausting so by using previously tested dishes, no recipes are needed and the process is perceived as much easier (Sidenvall et al., 2001). Some women with tremors choose to eat with a spoon in order to be able to eat independently, even though they commented on the fact that it was not culturally correct. The women who had suffered a stroke concentrated on being able to control their movements and activities again. If they could not cook themselves, being able to buy convenience food could be seen as a deliberate choice, at least in a transitional phase. This was a way of showing independence and managing the meal situation in relation to what and when to eat, despite the disease (Sidenvall et al., 2001; Gustafsson et al., 2003).

Having eating difficulties is described as something that has to be controlled and managed in every meal situation. Medin et al. showed that eating safely and eating properly were two expressions used in trying to gain and re-gain control of the eating situation even 6 months after a stroke (Medin, Larson, von Arbin, \& Wredling, 2010; Medin, Larson, von Arbin, Wredling, et al., 2010; Medin, Windahl, von Arbin, Tham, \& Wredling, 2011, 2012). To eat safely meant to eat without unwanted consequences such as choking and spitting, and eating properly was an expression for eating according to the cultural norms and values. In order to have control, the entire eating process is described as being an extremely conscious act. What to eat, the texture of the food, how to chew it and how big the bites should be, are some of the questions that have to be dealt with in every meal situation. Managing the meal situation may also include avoiding specific food as well as certain social contexts.

\section{Conclusion}

This literature overview showed several important aspects in understanding the food and meal situation among home-living elderly people with motoric eating difficulties, including nutritional status, food choice and preferences as well as the entire meal situation. Motoric eating difficulties make the important meal situation problematic in an already vulnerable group of elderly people, and may lead to decreased well-being and health in terms of risk for malnutrition and social isolation. Eating difficulties lead to the need for several adaptions with 
regard to food choice and preparation, as well as eating frequency. Experiences of guilt and shame may also affect the meal situation, resulting in social withdrawal. Eating difficulties often result in dependency on others during the meals. At the same time, independency is highly rated among the elderly. Supporting new preventive actions regarding food and meals such as the development of new and refined eating aids, may increase the possibility of an independent living. Furthermore, the importance of developing and enhancing food with respect to nutrient content and sensory liking as well as entire meal concepts that can be used together with these eating aids, should also be considered in order to promote health and to prevent malnutrition. In this respect, more attention should be given elderly with eating difficulties, focusing on food choice and preferences, as well as how to arrange for help and assistance regarding purchase and preparation of the food, and the actual eating situation.

\section{References}

Andersson, I., \& Sidenvall, B. (2001). Case studies of food shopping, cooking and eating habits in older women with Parkinson's disease. Journal of Advanced Nursing, 35(1), 69-78. http://dx.doi.org/10.1046/j.1365-2648.2001.01823.x

Andersson, J., Nydahl, M., Gustafsson, K., Sidenvall, B., \& Fjellström, C. (2003). Meals and snacks among elderly self-managing and disabled women. Appetite, 41(2), 149-160. http://dx.doi.org/10.1016/S0195-6663(03)00052-7

Aukner, C., Eide, H., D., \& Iversen, P. O. (2013). Nutritional status among older residents with dementia in open versus special care units in municipal nursing homes: an observational study. BMC Geriatrics, 13(26). http://dx.doi.org/10.1186/1471-2318-13-26

Backman, K., \& Hentinen, M. (1999). Model for the self - care of home - dwelling elderly. Journal of Advanced Nursing, 30(3), 564-572. http://dx.doi.org/10.1046/j.1365-2648.1999.01125.x

Bartali, B., Salvini, S., Turrini, A., Lauretani, F., Russo, C. R., Corsi, A. M., ... Ferrucci, L. (2003). Age and Disability Affect Dietary Intake. Journal of Nutrition, 133(9), 2868-2873.

Bauer, J., Biolo, G., Cederholm, T., Cesari, M., Cruz-Jentoft, A. J., Morley, J. E., ... Teta, D. (2013). Evidence-based recommendations for optimal dietary protein intake in older people: a position paper from the PROT-AGE Study Group. Journal of the American Medical Directors Association, 14(8), 542-559. http://dx.doi.org/10.1016/j.jamda.2013.05.021

Beck, A. M., \& Ovesen, L. (2002). Body mass index, weight loss and energy intake of old Danish residents and $\begin{array}{lllll}\text { home-care clients. Scandinavian Journal of Caring Sciences, 6, } & \text { 86-90. }\end{array}$ http://dx.doi.org/10.1046/j.1471-6712.2002.00062.x

Berg, G., Sarvimäki, A., \& Hedelin, B. (2006). Hospitalized older peoples' views of health and health promotion. International Journal of Older People Nursing, $1(1), \quad 25-33$. http://dx.doi.org/10.1111/j.1748-3743.2006.00007.x

Bergh, A. (2005). Kosher eller palt - maten är en del av vår identitet Mat för äldre - inom vård och omsorg. The National Board of Health and Welfare, Sweden (vol. 5, pp. 1-6).

Bülow, M., Camper, A., Ekman, S., Rothenberg, E., Sjöberg, K., Willén, E., \& Wendin, K. (2007). Äldre personers relation till mat, näring och måltidssituationer SIK-report 770: SIK.

Cabrera, C., Rothenberg, E., Eriksson, B. G., Wedel, H., Eiben, G., Steen, B., \& Lissner, L. (2006). Socio-economic gradient in food selection and diet quality among 70-year olds. The Journal of Nutrition, Health \& Aging, 11(6), 466-473.

Carlsson, E., Ehrenberg, A., \& Ehnfors, M. (2004). Stroke and eating difficulties: long - term experiences. Journal of Clinical Nursing, 13(7), 825-834. http://dx.doi.org/10.1111/j.1365-2702.2004.01023.x

Carlsson, M., Haglin, L., Rosendahl, E., \& Gustafson, Y. (2013). Poor nutritional status is associated with urinary tract infection among older people living in residential care facilities. The Journal of Nutrition, Health \& Aging, 17(2), 186-191. http://dx.doi.org/10.1007/s12603-012-0087-z

Christensson, L., Unosson, M., \& Ek, A.-C. (1999). Malnutrition in elderly people newly admitted to a community resident home. The Journal of Nutrition, Health \& Aging, 3, 133-139.

Daunfeldt, S.-O., Gustafsson, N., Hortlund, P., \& Rosén, E. (2009). Äldres konsumtionsmönster och preferenser: Swedish Institute of Retail (HUI), Sweden. 
de Castro, J. M. (2002). Age-related changes in the social, psychological, and temporal influences on food intake in free-living, healthy, adult humans. Journals of Gerontology Series A: Biological Sciences and Medical Sciences, 57(6), M368-M377. http://dx.doi.org/10.1093/gerona/57.6.M368

Edfors, E., \& Westergren, A. (2012). Home-living elderly people's views on food and meals. Journal of Aging Research, 2012, 1-9. http://dx.doi.org/10.1155/2012/761291

Ekberg, O., Hamdy, S., Woisard, V., Wuttge-Hannig, A., \& Ortega, P. (2002). Social and psychological burden of dysphagia: its impact on diagnosis and treatment. Dysphagia, 17(2), 139-146.

Elsner, R. J. F. (2002). Changes in eating behavior during the aging process. Eating Behaviors, 3(1), 15-43.

Engelheart, S., Lammes, E., \& Akner, G. (2005). Elderly peoples' meals. A comparative study between elderly living in a nursing home and frail, self-managing elderly. The Journal of Nutrition, Health \& Aging, 10(2), 96-102.

Fennell, G., Phillipson, C., \& Evers, H. (1988). The sociology of old age: (p. 224) Milton Keynes: Open University Press.

Field, D., \& Minkler, M (1988). Continuity and change in social support between young-old and old-old or very old age. Journal of Gerontology, 43, 100-106. http://dx.doi.org/10.1093/geronj/43.4.P100

Fjellström, C. (2009). The social significance of older people's meals. In M. M. Raats, L. d. Groot \& W. v. Staveren (Eds.), Food for the Ageing Population (pp. 95-109). Cambridge: Woodhead Publishing Limited. http://dx.doi.org/10.1201/9781439829189.ch5

Fjellström, C., \& Mattsson Sydner, Y. (2009). Måltidens sociala betydelse - ett äldreperspektiv. Nordisk Nutrition, 2, 10-11

Fjellström, C., Sidenvall, B., \& Nydahl, M. (2001). Food intake and the elderly: Social aspects. In L. Frewer, E. Risvik \& S. H (Eds.), Food, People and Society: A European Perspective of Consumers' Food Choices (pp. 197-209). Berlin: Springer-Verlag.

Giacalone, D., Duerlund, M., Bøegh-Petersen, J., Bredie, W. L. P., \& Frøst, M. B. (2014). Stimulus collative properties and consumers' flavor preferences. Appetite, $77(0), \quad 20$. http://dx.doi.org/10.1016/j.appet.2014.02.007

Given, B., \& Given, W. (1989). Cancer nursing for the elderly. A target for research. Cancer Nursing, 12, 71-77. http://dx.doi.org/10.1097/00002820-198904000-00003

González-Fernández, M., Ottenstein, L., Atanelov, L., \& Christian, A. B. (2013). Dysphagia after stroke: an overview. Current Physical Medicine and Rehabilitation Reports, 1(3), 187-196. http://dx.doi.org/10.1007/s40141-013-0017-y

Guigoz, Y. (2006). The Mini Nutritional Assessment (MNA®) review of the literature-what does it tell us? Journal of Nutrition, Health \& Aging, 10(6), 466-485.

Gustafsson, K., Andersson, I., Andersson, J., Fjellström, C., \& Sidenvall, B. (2003). Older Women's Perceptions of Independence Versus Dependence in Food-Related Work. Public Health Nursing, 20(3), 237-247. http://dx.doi.org/10.1046/j.0737-1209.2003.20311.x

Gustafsson, K., \& Sidenvall, B. (2002). Food-related health perceptons and food habits among older women. Journal of Advanced Nursing, 39(2), 164-173. http://dx.doi.org/10.1046/j.1365-2648.2002.02256.x

Hall, G., \& Wendin, K. (2008). Sensory Design of Foods for the Elderly. Annals of Nutrition and Metabolism, 52, 25-28. http://dx.doi.org/10.1159/000115344

Hockey, J., \& James, A. (1993). Growing up and growing old: ageing and dependency in the life course. London SAGE.

Irz, X., Fratiglioni, L., Kuosmanen, N., Mazzocchi, M., Modugno, L., Nocella, G., ... Zanello, G. (2014). Sociodemographic determinants of diet quality of the EU elderly: a comparative analysis in four countries. Public Health Nutrition, 17(5), 1177-1189. http://dx.doi.org/10.1017/S1368980013001146

Jacobsson, C., Axelsson, K., Österlind, P. O., \& Norberg, A. (2000). How people with stroke and healthy older people experience the eating process. Journal of Clinical Nursing, 9(2), 255-264. http://dx.doi.org/10.1046/j.1365-2702.2000.00355.x

Johansson, L. (2013). Foodwork and meals in everyday life among persons with dementia and their partners. (Doctoral), Jönköping University. (Dissertation series no. 45, 2013) 
Johansson, L., Sidenvall, B., Malmberg, B., \& Christensson, L. (2009). Who will become malnourished? A prospective study of factors associated with malnutrition in older persons living at home. The Journal of Nutrition, Health \& Aging, 13(10), 855-866. http://dx.doi.org/10.1007/s12603-009-0242-3

Johansson, U., Larsson, J., Rothenberg, E., Stene, C., Unosson, M., \& Bosaeus, I. (2006). [Nutritional care in hospitals. Swedish hospitals do not manage to follow the European committee's guidelines]. Lakartidningen, 103(21-22), 1718-1720, 1723-1714.

Johansson, Y., Bachrach-Lindström, M., Carstensen, J., \& Ek, A. (2008). Malnutrition in a home-living older population: prevalence, incidence and risk factors. A prospective study. Journal of Clinical Nursing, 18(9), 1354-1364. http://dx.doi.org/10.1111/j.1365-2702.2008.02552.x

Kallio, M. K., Koskinen, S. V. P., \& Prättälä, R. S. (2008). Functional disabilities do not prevent the elderly in Finland from eating regular meals. Appetite, 51(1), 97-103. http://dx.doi.org/10.1016/j.appet.2007.12.006

Keller, H. H. (2006). The SCREEN I (Seniors in the Community: Risk Evaluation for Eating and Nutrition) index adequately represents nutritional risk. Journal of Clinical Epidemiology, 59(8), 836-841. http://dx.doi.org/10.1016/j.jclinepi.2005.06.013

Kondrup, J., Allison, S., Elia, M., Vellas, B., \& Plauth, M. (2003). ESPEN guidelines for nutrition screening 2002. Clinical Nutrition, 22(4), 415-421. http://dx.doi.org/10.1016/S0261-5614(03)00098-0

Koskinen, S., Kälviäinen, N., \& Tuorila, H. (2003). Flavor enhancement as a tool for increasing pleasantness and intake of a snack product among the elderly. Appetite, 41(1), 87-96. http://dx.doi.org/10.1016/S0195-6663(03)00054-0

Kullberg, K., Aberg, A. C., Bjorklund, A., Ekblad, J., \& Sidenvall, B. (2008). Daily eating events among co-living and single-living, diseased older men. The Journal of Nutrition, Health \& Aging, 12(3), 176-182. http://dx.doi.org/10.1007/BF02982615

Kullberg, K., Björklund, A., Sidenvall, B., \& Åberg, A. C. (2011). 'I start my day by thinking about what we're going to have for dinner'- a qualitative study on approaches to food-related activities among elderly men with somatic diseases. Scandinavian Journal of Caring Sciences, 25(2), 227-234. http://dx.doi.org/10.1111/j.1471-6712.2010.00813.x

Kumlien, S., \& Axelsson, K. (2002). Stroke patients in nursing homes: eating, feeding, nutrition and related care. Journal of Clinical Nursing, 11(4), 498-509. http://dx.doi.org/10.1046/j.1365-2702.2002.00636.x

Leopold, N. A., \& Kagel, M. C. (1997). Dysphagia-Ingestion or Deglutition?: A Proposed Paradigm. Dysphagia, 12(4), 202-206. http://dx.doi.org/10.1007/PL00009537

Lochs, H., Allison, S. P., Meierc, R., Pirlich, M., Kondrup, J., Schneider, S., ... Pichard, C. (2006). Introductory to the ESPEN guidelines on enteral nutrition: terminology, definitions and general topics. Clinical Nutrition, 25, 180-186. http://dx.doi.org/10.1016/j.clnu.2006.02.007

Lorefält, B., Ganowiak, W., Wissing, U., Granerus, A., \& Unosson, M. (2006). Food habits and intake of nutrients in elderly patients with Parkinson's disease. Gerontology, 52(3), 160-168. http://dx.doi.org/10.1159/000091825

Lorefält, B., Unosson, M., \& Granerus, A. (2006). Avoidance of solid food in weight losing older patients with Parkinson's disease. Journal of Clinical Nursing, 15(11), 1404-1412. http://dx.doi.org/10.1111/j.1365-2702.2005.01454.x

Lundin, H., Lundin, H., Sääf, M., Strender, L., \& Mollasaraie, H. A. (2012). Mini nutritional assessment and 10 -year mortality in free-living elderly women: a prospective cohort study with 10-year follow-up. European Journal of Clinical Nutrition, 66(9), 1050-1053. http://dx.doi.org/10.1038/ejen.2012.100

Lundkvist, P., Fjellström, C., Sidenvall, B., Lumbers, M., \& Raats, M. (2010). Management of healthy eating in everyday life among senior Europeans. Appetite, 55(3), 616-622. http://dx.doi.org/10.1016/j.appet.2010.09.015

Maitre, I., Van Wymelbeke, V., Amand, M., \& Vigneau, E. (2014). Food pickiness in the elderly: Relationship with dependency and malnutrition. Food quality and preference, 32, 145-151. http://dx.doi.org/10.1016/j.foodqual.2013.04.003

Mattsson Sydner, Y. (2002). The Unempowered Meal : About food and meals in the elderly-care. Uppsala University, Uppsala. 
Mattsson Sydner, Y., \& Fjellström, C. (2006). The meaning of symbols of culinary rules - The food and meals in Elderly care. Journal of Foodservice, 17(4), 182-188. http://dx.doi.org/10.1111/j.1745-4506.2006.00036.x

Mattsson Sydner, Y., \& Fjellström, C. (2007). Illuminating the (non-)meaning of food: organization, power and responsibilities in public elderly care - a Swedish perspective. Journal of Foodservice, 18(3), 119-129. http://dx.doi.org/10.1111/j.1745-4506.2007.00056.x

Mattsson Sydner, Y., Sidenvall, B., Fjellström, C., Raats, M., \& Lumbers, M. (2007). Food Habits and Foodwork: The Life Course Perspective of Senior Europeans. Food, Culture and Society, 10(3), 367-387. http://dx.doi.org/10.2752/155280107X239845

McKie, L., MacInnes, A., Hendry, J., Donald, S., \& Peace, H. (2000). The food consumption patterns and perceptions of dietary advice of older people. Journal of Human Nutrition and Dietetics, 13(3), 173-183. http://dx.doi.org/10.1046/j.1365-277x.2000.00226.x

McLaren, S. M. G., \& Dickerson, J. W. T. (2000). Measurement of eating disability in an acute stroke population. Clinical Effectiveness in Nursing, 4(3), 109-120. http://dx.doi.org/10.1054/cein.2000.0128

Medin, J., Larson, J., von Arbin, M., \& Wredling, R. (2010). Elderly persons' experience and management of eating situations 6 months after stroke. Disability and Rehabilitation, 32(16), 1346-1353. http://dx.doi.org/10.3109/09638280903514747

Medin, J., Larson, J., von Arbin, M., Wredling, R., \& Tham, K. (2010). Striving for control in eating situations $\begin{array}{lllll}\text { after stroke. Scandinavian Journal of Caring Sciences, 24(4), } & \text { 772-780. }\end{array}$ http://dx.doi.org/10.1111/j.1471-6712.2010.00775.x

Medin, J., Windahl, J., von Arbin, M., Tham, K., \& Wredling, R. (2011). Eating difficulties among stroke patients in the acute state: a descriptive, cross - sectional, comparative study. Journal of clinical nursing, 20(17-18), 2563-2572. http://dx.doi.org/10.1111/j.1365-2702.2011.03812.x

Medin, J., Windahl, J., von Arbin, M., Tham, K., \& Wredling, R. (2012). Eating difficulties among patients 3 months after stroke in relation to the acute phase. Journal of Advanced Nursing, 68(3), 580-589. http://dx.doi.org/10.1111/j.1365-2648.2011.05759.x

Methven, L., Allen, V. J., Withers, C. A., \& Gosney, M. A. (2012). Ageing and taste. Paper presented at the The Annual Meeting of BAPEN with the Nutrition Society, Harrogate.

Nordenskiöld, U. (1997). Daily activities in women with rheumatoid arthritis. Aspects of patient education, assistive devices and methods for disability and impairment assessment. Scandinavian Journal of Rehabilitation Medicine. Supplement, 37, 1-72.

Nordin, S., Brämerson, A., Bringlöv, E., Kobal, G., Hummel, T., \& Bende, M. (2007). Substance and tongue-region specific loss in basic taste-quality identification in elderly adults. European Archives of Otorhinolaryngology, 264(3), 285-289. http://dx.doi.org/10.1007/s00405-006-0169-9

Pajalic, Z. (2013). Food preparation at home an example of new practical strategies in the Swedish municipal food service - A qualitative study. Journal of Food Research, 2(6), 72-79. http://dx.doi.org/10.5539/jfr.v2n6p72

Pajalic, Z., Persson, L., Westergren, A., Berggren, V., \& Skovdahl, K. (2012). The experiences of elderly people living at home related to their receiving meals distributed by a municipality in Sweden. Journal of Food Research, 1(1), 68-78. http://dx.doi.org/10.5539/jfr.v1n1p68

Rasheed, S., \& Woods, R. T. (2013). Malnutrition and quality of life in older people: A systematic review and meta-analysis. Ageing Research Reviews, 12(2), 561-566. http://dx.doi.org/10.1016/j.arr.2012.11.003

Rasmussen, H., H., Kondrup, J., Staun, M., Ladefoged, K., Kristensen, H. \& Wengler, A. (2004). Prevalence of patients at nutritional risk in Danish hospitals. Clinical Nutrition, 23, 1009-1015. http://dx.doi.org/10.1016/j.clnu.2004.01.001

Roininen, K., Fillion, L., Kilcast, D., \& Lähteenmäki, L. (2004). Exploring difficult textural properties of fruit and vegetables for the elderly in Finland and the United Kingdom. Food Quality and Preference, 15(6), 517-530. http://dx.doi.org/10.1016/j.foodqual.2003.11.003

Rothenberg, E., Bosaeus, I., \& Steen, B. (1994). Food habits, food beliefs and socio-economic factors in an eldery population. Scandinavian Journal of Nutrition, 38(4), 159-165. 
Rothenberg, E., Ekman, S., Bülow, M., Möller, K., Svantesson, J., \& Wendin, K. (2007). Texture-modified meat and carrot products for elderly people with dysphagia: preference in relation to health and oral status. Scandinavian Journal of Food and Nutrition, 51(4), 141-147. http://dx.doi.org/10.1080/17482970701760675

Russell, C., \& Elia, M. (2012). Nutrition screening survey in the UK and Republic of Ireland in 2011: nutrition screening survey and audit of adults on admission to hospitals, care homes and mental health units: main data collection. Redditch BAPEN.

Russell, C. A., \& Elia, M. (2008). Nutrition screening survey in the UK in 2007: Nutrition screening survey and audit of adults on admission to hospital, care homes and mental health units: main data collection. Redditch: BAPEN.

Russell, C. A., \& Elia, M. (2010). Malnutrition in the UK: where does it begin? Proceedings of the Nutrition Society, 69, 465-469. http://dx.doi.org/10.1017/S0029665110001850

Saletti, A. (2007). Nutritional status and mealtime experiences in elderly care recipients: Doctoral dissertation. Department of Neurobiology, Care Sciences and Society, Division of Clinical Nutrition, Karolinska Insitutet, Stockholm, Sweden.

Schiffman, S. S. (1998). Sensory enhancement of foods for the elderly with monosodium glutamate and flavors. Food Reviews International, 14(2-3), 321-333. http://dx.doi.org/10.1080/87559129809541164

Shahar, D. R., Schultz, R., Shahar, A., \& Wing, R. R. (2001). The effect of widowhood on weight change, dietary intake, and eating behavior in the elderly population. Journal of Aging and Health, 13(2), 189-199. http://dx.doi.org/10.1177/089826430101300202

Sidenvall, B., \& Fjellstrom, C. (1994). The meal situation in geriatric care-intentions and experiences. Journal of Advanced Nursing, 20(4), 613-621. http://dx.doi.org/10.1046/j.1365-2648.1994.20040613.x

Sidenvall, B., Fjellström, C., \& Ek, A.-C. (1996). Cultural perspectives of meals expressed by patients in geriatric care. International Journal of Nursing Studies, 33(3), 212-222. http://dx.doi.org/10.1016/0020-7489(95)00042-9

Sidenvall, B., Fjellström, C., \& Ek, A. C. (1994). Cultural conceptions of daily planning of meals in geriatric care. Vård $i$ Norden, 14(2-3), 613-621. http://dx.doi.org/10.1046/j.1365-2648.1994.20040613.x

Sidenvall, B., Nydahl, M., \& Fjellström, C. (2000). The meal as a gift - the meaning of cooking among retired women. Journal of Applied Gerontology, 19(4), 405-423. http://dx.doi.org/10.1177/073346480001900403

Sidenvall, B., Nydahl, M., \& Fjellström, C. (2001). Managing Food Shopping and Cooking: The Experiences of Older Swedish Women. Ageing and Society, 21(2), 151-168. http://dx.doi.org/10.1017/S0144686X01008121

Soini, H., Routasalo, P., \& Lauri, S. (2006). Nutrition in patients receiving home care in Finland: tackling the multifactorial problem. Journal of Gerontological Nursing, 32(4), 12-17.

Strandberg, G. (2002). Beroende av vård. Innebörden av fenomenet som det visar sig genom patienters, deras anhörigas och vårdares berättelser. Umeå Universitet, Umeå. (Umeå medica dissertations. New Series No 768)

Söderhamn, U., Dale, B., Sundsli, K., \& Söderhamn, O. (2012). Nutritional screening of older home-dwelling Norwegians: a comparison between two instruments. Clinical Interventions in Aging, 7, 383-391. http://dx.doi.org/10.2147/CIA.S35986

Söderström, L., Thors Adolfsson, E., Rosenblad, A., Frid, H., Saletti, A., \& Bergkvist, L. (2013). Mealtime habits and meal provision are associated with malnutrition among elderly patients admitted to hospital. Clinical Nutrition, 32(2), 281-288. http://dx.doi.org/10.1016/j.clnu.2012.07.013

Tangvik, R. J., Tell, G. S., Guttormsen, A. B., Eisman, J. A., Henriksen, A., Nilsen, R. M \& Ranhoff, A. H. (2014). Nutritional risk profile in a university hospital population. Clinical Nutrition (In Press) http://dx.doi.org/10.1016/j.clnu.2014.08.001.

Tieland, M., Borgonjen-Van den Berg, K. J., van Loon, L. J., \& de Groot, L. C. (2012). Dietary protein intake in community-dwelling, frail, and institutionalized elderly people: scope for improvement. European Journal of Nutrition, 51(2), 173-179. http://dx.doi.org/10.1007/s00394-011-0203-6 
Tuorila, H., Lähteenmäki, L., Pohjalainen, L., \& Lotti, L. (2001). Food neophobia among the Finns and related responses to familiar and unfamiliar foods. Food Quality and Preference, 12(1), 29-37. http://dx.doi.org/10.1016/S0950-3293(00)00025-2

Törmä, J., Winblad, U., Cederholm, T., \& Saletti, A. (2013). Does undernutrition still prevail among nursing home residents? Clinical Nutrition, 32(4), 562-568. http://dx.doi.org/10.1016/j.clnu.2012.10.007

Vallén, C., Hagell, P., \& Westergren, A. (2011). Validity and user-friendliness of the minimal eating observation and nutrition form-version II (MEONF-II) for undernutrition risk screening. Food and Nutrition Research, 55(5801). http://dx.doi.org/10.3402/fnr.v55i0.5801

Westergren, A., Axelsson, C., Lilja-Andersson, P., Lindholm, C., Petersson, K., \& Ulander, K. (2009). Study circles to improve the precision in nutritional care in special accomodations. Food and Nutrition Research, 53. http://dx.doi.org/10.3402/fnr.v53i0.1950

Westergren, A., Hagell, P., \& Sjodahl Hammarlund, C. (2014). Malnutrition and risk of falling among elderly without home-help service - a cross sectional study. The Journal of Nutrition, Health \& Aging, 1-7.

Westergren, A. \& Hedin, G. (2010). Do study circles and nutritional care policy improve nutritional care in a short- and long-term perspective in special accomodations? Food and Nutrition Research, 54.

Westergren, A., Karlsson, S., Andersson, P., Ohlsson, O., \& Hallberg, I. R. (2001). Eating difficulties, need for assisted eating, nutritional status and pressure ulcers in patients admitted for stroke rehabilitation. Journal of Clinical Nursing, 10(2), 257-269. http://dx.doi.org/10.1111/j.1365-2702.2001.00479.x

Westergren, A., Lindholm, C., Axelsson, C., \& Ulander, K. (2008). Prevalence of eating difficulties and malnutrition among persons within hospital care and special accommodations. The Journal of Nutrition Health and Aging, 12(1), 39-43. http://dx.doi.org/10.1007/BF02982162

Westergren, A., Lindholm, C., Mattsson, A., \& Ulander, K. (2009). Minimal eating observation form: Reliability and validity. JNHA - The Journal of Nutrition, Health and Aging, 13(1), 6-11. http://dx.doi.org/10.1007/s12603-009-0002-4

Westergren, A., Norberg, E., \& Hagell, P. (2011). Diagnostic performance of the Minimal Eating Observation and Nutrition Form-Version II (MEONF-II) and Nutritional Risk Screening 2002 (NRS 2002) among hospital inpatients-a cross-sectional study. BMC Nursing, 10(24).

Westergren, A., Norberg, E., Vallén, C., \& Hagell, P. (2011). Cut-off scores for the Minimal Eating Observation and Nutrition Form-Version II (MEONF-II) among hospital inpatients. Food and Nutrition Research, 55.

Westergren, A., Ohlsson, O., \& Hallberg, I. (2001). Eating difficulties, complications and nursing interventions during a period of three months after a stroke. Journal of Advanced Nursing, 35(3), 416-426. http://dx.doi.org/10.1046/j.1365-2648.2001.01884.x

Westergren, A., Unosson, M., Ohlsson, O., Lorefält, B., \& Hallberg, I. R. (2002). Eating difficulties, assisted eating and nutritional status in elderly ( $\geqslant 65$ years) patients in hospital rehabilitation. International Journal of Nursing Studies, 39(3), 341-351. http://dx.doi.org/10.1016/S0020-7489(01)00025-6

Westergren, A., Wann-Hansson, C., Börgdal, E. B., Sjölander, J., Strömblad, R., Klevsgård, R., ... Ulander, K. (2009). Nutrition Journal, 8, 20. http://dx.doi.org/10.1186/1475-2891-8-20

Weurlander, I., \& Gurner, U. (2006). Maten - en serviceinsats. Hur äldre som har omfattande hemtjänst ser på sin hjälp med måltiderna (Report, vol. 2): Stiftelsen Stockholms läns Äldrecentrum.

WHO (2002). Active Ageing: A policy framework. A contribution of the World Health Organization to the second United Nations World Assembly on Ageing, Madrid, Spain, April, 2002. World Health Organisation, Geneva (1-60)

Wikby, K., Ek, A., \& Christensson, L. (2006). Nutritional status in elderly people admitted to community residential homes: comparisons between two cohorts. Journal of Nutrition Health and Aging, 10(3), 232.

Wikby, K., Ek, A. C., \& Christensson, L. (2008). The two - step Mini Nutritional Assessment procedure in community resident homes. Journal of Clinical Nursing, 17(9), 1211-1218. http://dx.doi.org/10.1111/j.1365-2702.2007.02012.x

Wikby, K., \& Fägerskiöld, A. (2004). The willingness to eat. An investigation of appetite among elderly people. $\begin{array}{lllll}\text { Scandinavian Journal of Caring } & \text { Sciences, } & 18(2), & \text { 120-127. }\end{array}$ http://dx.doi.org/10.1111/j.1471-6712.2004.00259.x 
Wylie, K., \& Nebauer, M. (2011). “The Food Here Is Tasteless!” Food taste or tasteless food? Chemosensory Loss and the Politics of Under-Nutrition. Collegian, 18(1), 27-35. http://dx.doi.org/10.1016/j.colegn.2010.03.002

\section{Copyrights}

Copyright for this article is retained by the author(s), with first publication rights granted to the journal.

This is an open-access article distributed under the terms and conditions of the Creative Commons Attribution license (http://creativecommons.org/licenses/by/3.0/). 